\title{
BAD WORDS IN THE GOOD PLACE: ANALYZING THE EUPHEMISTIC FUNCTION OF WORDPLAYS IN SUBTITLING AND DUBBING - A CASE OF ENGLISH AND PORTUGUESE LANGUAGE PAIR
}

\author{
Adauri Brezolin ${ }^{1 i}$, \\ Fernanda da Silva Medeiros ${ }^{2}$ \\ ${ }^{1} \mathrm{PhD}$ in English Language, \\ Independent Researcher, \\ Brazil \\ ${ }^{2}$ Undergraduate in Translation, \\ Methodist University of São Paulo, \\ Brazil
}

\begin{abstract}
:
In this paper, we examine the translation of euphemistic wordplays used in The Good Place, an American fantasy comedy television series. Twenty-eight wordplays, resulting from censored curse words, were collected from the Netflix platform, and compared with their counterparts in Brazilian Portuguese, to verify whether the adopted linguistic mechanisms preserved their pragmatic effect, and whether they were consistently transferred into the target language in the dubbed and subtitled versions of the series. Our study basically drew on the ideas by Delabastita (1996); Gotlieb (1997); Tagnin (2005); Diaz Cintas (2010); Dias Cintas \& Orero (2010); Remael (2010); Darta (2020), and Brezolin (2020a). Our results demonstrate that, out of the 28 occurrences, 25 wordplays in the dubbed version and 10 in the subtitled version were successfully transferred into the target language, that is, they were adapted to the local setting, and then, preserved their humorous effect; and 3 in the dubbed version and 18 in the subtitled version were replaced by non-wordplays, or omitted. The successful results in the target language were not so consistent as the original excerpts in terms of lexical choices, and the dubbed version demonstrated to be more consistent once most of the wordplays were translated, and more suitable lexical items were selected to generate them.
\end{abstract}

Keywords: translation, dubbing, subtitling, wordplay, taboo words

\section{Introduction}

Like other linguistic events, such as jokes, wordplays can be either admired or disdained depending on their quality; as put by Stanford, "( $n$ )othing is more futile than the irrelevant pun that is based on only a verbal similarity and brings out no contrast, innuendo, or congruity of meaning" (qtd.

i Correspondence: email brezolinadau@yahoo.com.br 
in Redfern 1984: 20). However, the type of wordplay we analyze here brings out, especially innuendo, since they are used euphemistically, and, as such, attempt to circumvent taboo words. We believe, as Redfern states, that "puns illuminate the nature of language in general" (1984: 9). So, by detecting the potentialities of a given language, and thanks to their cleverness, punsters may come out with creative linguistic constructions that can serve different purposes, as we will see.

The wordplays examined in this paper were collected from the lines of "amoral loner Eleanor", the leading character of the American television series, The Good Place, "a paradise of eternal happiness", where she has been sent to after death. There, cursing is forbidden, and every time she attempts to say bad words, they are replaced by phonologically similar "good" words, thus, generating wordplays. Our objective is to analyze the mechanisms used to create such wordplays, and, later, compare them with their counterparts in the versions subtitled and dubbed into Brazilian Portuguese, to verify how they were treated, whether their pragmatic effect was preserved, and whether solutions presented in the target language showed consistency. Our theoretical framework is presented in the next section.

\section{Literature review}

In this section, we offer an overview of the main concepts relevant to our analysis, such as audiovisual translation, especially dubbing and subtitling, and the creation, functions as well as the translation of wordplays.

\subsection{Audiovisual translation: dubbing and subtitling}

According to Diaz Cintas, audiovisual translation (AVT) "is the umbrella term used to refer to the translation of programmes in which the verbal dimension is only one of the many shaping the communication process" (2010: 344). For Diaz Cintas \& Orero, two fundamental approaches fall under this term: (a) oral output remains oral output, and (b) oral output becomes written output. From them, different modes have developed, such as subtitling for the stage; subtitling for the deaf and hard of hearing (SDH); live subtitling with speech recognition; fansubbing and fandubbing; audio description (AD) for the blind; video game localization, just to mention a few (Remael 2010). However, our focus, in this paper, will be on two basic subcategories: dubbing and subtitling.

Dubbing "involves replacing the original soundtrack containing the actors' dialogue with a TL recording that reproduces the original message, ensuring that the TL sounds and the actors' lip movements are synchronised in such a way that target viewers are led to believe that the actors on screen are actually speaking their language" (Diaz Cintas \& Orero 2010: 442), and subtitling "consists in rendering in writing the translation into a TL of the original dialogue exchanges uttered by the different speakers, as well as of all other verbal information that is transmitted visually (letters, banners, inserts) or aurally (lyrics, voices off)" (Diaz Cintra 2010: 344). As Gottlieb puts it, television is polysemiotic, i. e., "communication which simultaneously employs two or more channels of discourse. In television, four such channels share the communicative tasks involved: picture, written text, dialogue and music/sound effects" (1997: 210). 
Though dubbing and subtitling produce different outputs, they operate under one same constraint: time. In dubbing, there is "the need for various forms of synchrony between text and image/sound", and in subtitling, the written text must coincide with the original dialogue and other sounds as well as remain on the screen time enough for viewers to read it. Subtitling also operates under another constraint: space, since translators need "to compress, paraphrase and adapt speech to a hybrid form of writing". (Remael 2010: 15)

Understanding these two categories of AVT is important for our analysis; in particular, when professionals must deal with wordplays either to be dubbed or subtitled, since rendering them becomes more challenging due to the particularities of this linguistic event and the specific constraints of each mode of language transfer. What about when translators encounter wordplays generated from taboo words?

\subsubsection{AVT and taboo words}

According to Darta, "(t)ranslating swearing words has become an interesting study to conduct, especially because it involves two different languages that carry different social values". (2020: 25) For her, in some cultures, swearing words may be allowed in subtitles, in others, their use might be restricted.

Restriction seemed to be the case until recently in Brazil, where more offensive words and expressions present in films were usually replaced with "politer" ones, as stated by Nunes (2012), in her Master Thesis about subtitles collected from pay-television channels in that country. She argues that censorship was (or perhaps still is) imposed by multichannel television providers who adopted restriction on cursing words by justifying that reading them in subtitles is more offensive than listening to them in dubbed films, for example. Out of the 11 channels investigated by her, in only one, she observed the use of dirty language; in the others, they were simply substituted or omitted. This seems (or seemed) to be the norm in other countries, as well, such as in Italy (Beseghi 2016), Spain (Ávila-Cabrera 2016), and Indonesia (Darta 2020), for instance.

In effect, if translators encountered wordplays produced with taboo words, they would have to follow the rules imposed by the translation commissioner, replacing, attenuating, or omitting them. However, the wordplays we analyze here have already been "censored", so the translator had to deal with their camouflaged versions. Interestingly, in terms of impact, due to the prevailing mechanism employed to conceal them - paronymy (as we will see later) -, the words, supposedly "disguised", are still evident to viewers. Now, we turn to how wordplays can be defined and used.

\subsection{Wordplays: definitions and functions}

In a recent study, Brezolin (2020a) revisited the following definitions of wordplays:

- "any adaptation or use of words to achieve a humorous, satirical, dramatic, critical, or other effect" (MacArthur 1992: 787);

- "(w)ordplay is the general name for the various textual phenomenon in which structural features of the language(s) used are exploited in order to bring about a communicatively significant 
confrontation of two (or more) linguistics structures with more or less similar forms and more or less different meanings" (Delabastita 1996: 128);

- "the function of most wordplay is to create a comic effect and attract the attention of the reader or listener to a specific point in the text" (Veisbergs 1997: 159);

- "the stylistic manipulation of the lexis (and semantics) of fixed expressions and idioms is perhaps to provide some sort of defamiliarization, and typically providing humour" (Moon 1998: 170);

- "wordplay is characterized as a clever and creative exploitation of the meaning and form of words" (Langlotz 2006: 195), and

- "the clever manipulation of the form of a language string or the use of polysemy resulting in an amusing effect" (Arnaud, Maniez \& Renner 2015: 136).

After studying them, Brezolin came out with the following definition, which is adopted in this paper: "any clever and creative manipulation through the confrontation of meaning and forms of one or two words, or of multi-word combinations, capable of causing, in readers/listeners/viewers, a primary reaction of surprise; subsequently, bringing about amusing, comic, critical, dramatic, humorous, satirical, and other effects" (2020a: 214).

When it comes to the functions of wordplays, they can serve different purposes, for example: "unique opportunities for the teaching of translation" (Ballard 1996: 333); "attract the attention of the reader or listener to a specific point in the text" (Veisbergs 1997: 159); "conceal taboo" (Zirker \& Winter-Froemel 2015: 1); "as a didactic resource to be used with translation students", and "address taboo issues without sounding rude or inappropriate" (Brezolin 2020a: 215-219), among others.

Accordingly, Redfern (1984: 1) states that, "in the case of irony, taboo and euphemism", punning "can also be a cover-up job", this function is of great interest to us since, as the wordplays investigated here are euphemistic, they are employed to camouflage swear words.

By the way, in this paper, euphemism is defined as "an indirect word or phrase that people often use to refer to something embarrassing or unpleasant, sometimes to make it seem more acceptable than it really is"ii. This figure of speech is used as a strategy to mitigate the unpleasant impact of certain words or expressions, replacing them with more neutral words, expressions, or rewordings. Correspondingly, the use of such resource followed by the insertion of a laugh track in the episodes of the series was reason enough for us to consider the wordplays humorous. In the next subsection, we discuss the most common mechanisms used to produce them.

\subsection{Creating wordplays}

The generation of wordplays involves mechanisms related to the semantic relationship established among words. The most common ones involving one or two wordsiii are now presented, illustrated with our own examples:

- homonymy [identical sound, identical spelling, as in rock (stone)/rock (verb - to sway)];

\footnotetext{
ii Euphemism (2021): Oxford Learners Dictionaries, Retrieved: March 20, 2021. Available at: https://www.oxfordlearnersdictionaries.com/us/definition/english/euphemism?q=euphemism iii For studies on multi-word combinations, see Veisbergs (1997); Viégas-Faria (2004); Dore (2010), and Brezolin (2020b), for instance.
} 
- homophony [identical sound, different spelling, as in rain/rein];

- homography [different sound, identical spelling, as in bow (verb to bend) \'bau' , and bow (arc) \'bō \];

- paronymy [similar sound, similar spelling, as in affect/effect];

- polysemy [(same spelling, different, but related sense, as in bed (piece of furniture)/bed (ground for plants)] (Delabastita 1996; Tagnin 2005; Giorgadze 2014);

- synonymy [the same or nearly the same meaning in some or all senses, as in body/corpus], concerning "body lift" and "corpus lift" (Brezolin 2020a: 212), and

- portmanteau words, lexical blending, blend [the act of coalescing several words into one after an act of clipping, of overlapping, or of both clipping and overlapping, as in avigation (avi + navigation - aerial navigation); Brangelina (Brad + Angelina), and underwhelm (under + overwhelm)], just to mention a few (Renner 2015: 121).

Our analyses, though, will focus on paronymy as most of our excerpts extracted from the television series fall into this category.

\subsection{Translating wordplays}

As we know, in translation, there is no one-to-one interlingual correspondence, so, while authors produce creative combinations, relying on the morphological, phonological, lexical, syntactic, semantic, and pragmatic particularities of the source language, translators, as far as possible, must (or, at least, should) reproduce equally creative combinations, considering the characteristics and potentialities of the target language.

To carry out this challenging task, translators can, for example, appeal to Delabastita's suggestions for translating wordplays. His strategies are briefly presented below: 1) PUN into PUN; 2) PUN into NON-PUN; 3) PUN into RELATED RHETORICAL DEVICE; 4) PUN into ZERO; 5) PUN S.T. = PUN T.T.; 6) NON-PUN into PUN; 7) ZERO into PUN, and 8) EDITORIAL TECHNIQUES (1996: 133-134)

However, as the object of our study refers to subtitling and dubbing, we understand that Gottlieb's (1997) strategies for translating wordplays suit our purpose better. Although he applied them in the analyses of subtitles, we believe they can also be useful to analyze dubbed television show dialogues.

According to Gottlieb, wordplays can be:

a) "rendered verbatim, with or without humorous effect;

b) adapted to the local setting, to maintain humorous effect;

c) replaced by non-wordplay;

d) not rendered, using the space for neighbouring dialogue;

e) inserted in different textual positions, where the target language renders it possible" (1996: 210).

Based on our data, as we will see further, we believe that strategy (c), "replaced by nonwordplay", can branch out into "replaced by non-wordplay with omission, preserving or not the humorous effect", where the wordplay is omitted and the whole fragment in which it appears is

\footnotetext{
iv For an expansion of Delabastita's wordplay translation strategies, refer to Silva (2019).
} 
(a) translated (almost) literally, or (b) replaced by something quite different from the source linguistic construction. These strategies will be applied in our analysis.

\section{The study corpus and euphemistic wordplays}

Our study corpus consisted of 13 transcripts $^{v}$ (Season 1) of The Good Place, an American fantasy comedy television series, centered around a paradise where only those who have been good throughout their lives go to once they have passed away. Otherwise, they may also go to "The Bad Place", or to "The Medium Place", depending on how their actions on Earth are evaluated. Sent to "the good place", supposedly, by mistake, "amoral loner Eleanor", one of the main characters is censored whenever she tries to say curse words, something that takes place mostly in Season 1. The show, created by Michael Schur, was premiered on NBC on September 19, 2016, and concluded on January 30, 2020, after four seasons and 53 episodes ${ }^{\mathrm{vi}}$. It has been broadcast in Brazil by Netflix in Portuguese dubbed and subtitled versions. Our interest in a specific word for further analysis was motivated by the following dialogue between Eleanor and another character, when she was trying to convince him that she was not the person they thought she was:

- Are you sure this isn't you?

- Yeah, man, I'm pretty sure I wasn't a death row lawyer who collected clown paintings and rescued orphans. They got my name right, but nothing else. I mean, somebody royally forked up. Somebody forked up. Why can't I say "fork"?

- If you're trying to curse, you can't here. I guess a lot of people in this neighborhood don't like it, so it's prohibited. vii

The word "fork" (referring to "fuck") and its inflected forms, all used euphemistically, hinted that they could be abundant in the episodes, as it was later confirmed, when we compiled a corpus with the transcripts of Season 1. These transcripts, which were copied, pasted into a .txt file, and run with the AntConc concordance tool (Anthony 2020), amounted to 44,712 tokens. Through the basic features of the software, a word list, in alphabetical order, was provided $(4,590$ types); thus, "fork" and its inflected forms became search words (Figure 1).

\footnotetext{
v Subslikescript (2019): The Good Place - Episodes (online). Retrieved: June 4, 2019. Available at: https://subslikescript.com/series/The Good Place-4955642

vi WIKIPEDIA (2021): The Good Place (TV Series) (online). Retrieved: March 24, 2021. Available at: https://en.wikipedia.org/wiki/The Good Place

vii Subslikescript (2021): The Good Place - Episode 1 - Pilot (online). Retrieved: March 25, 2021. Available at: https://subslikescript.com/series/The Good Place-4955642/season-1/episode-1-Pilot
} 
Figure 1: AntConc print screen: "fork" and inflected forms

\begin{tabular}{|l|l|l|}
\hline 1589 & 20 & fork \\
1590 & 4 & forked \\
1591 & 1 & forkers \\
1592 & 2 & forkin \\
1593 & 3 & forking \\
1504 & 2 & form \\
\hline
\end{tabular}

(Prepared by authors, 2021)

Then, through the concordance feature of the software, concordance lines were obtained by clicking on each of the words of interest. In Figure 2, we can see the result of this procedure for "fork":

Figure 2: AntConc print screen: concordance lines with "fork"

\begin{tabular}{|c|c|}
\hline 1 & no idea where she is. - Well, what the - What? - Fork! - [crunching] I will now review Eleanor's memori \\
\hline 2 & ient, and kind, and surprisingly jacked, and, oh, fork, I'm in love with Chidi. Let's take \\
\hline 3 & up. Somebody forked up. Why can't I say "fork"? If you're trying to curse, you can't \\
\hline 4 & it in my mouth. What? [dramatic music] What the fork is a "Chidi"? Why can't I say "fork"? \\
\hline 5 & , I'm just trying to figure out what the fork is happening. I think we might be in an \\
\hline 6 & ow? You sent me these threatening notes? What the fork, man? Some Buddhist monk you are. You don't \\
\hline 7 & leanor, this is all happening because of you. Ah, fork me. Okay, okay. We don't know this is \\
\hline 8 & bout Stupid Nick. We need a distraction right the fork now. No, no, no, no, no. Eleanor, Chef Patricia \\
\hline 9 & they are. Bad Janet? - [tone chimes] - What's up, fork nuts? Engage walkie-talkie protocol. [electronic \\
\hline 10 & 's not working. Not one more point. What the fork? Oh, look, Michael's here. He can help. Michael, \\
\hline 11 & 's staying here. Now, all of you Get the fork out of my neighborhood. [suspenseful music] [chuc \\
\hline 12 & fork is a "Chidi"? Why can't I say " fork"? Read more: https://www.springfieldspringfield \\
\hline 13 & a bit burned. But they're not. Hmm. Oh, fork, that's good. Extra, extra! Read all about you. \\
\hline 14 & 'Cause I can't resist it no more Oh, fork. The part when I say I don't want \\
\hline 15 & ters. [gasps] [laughs] It's working! Ow! What the fork? [thunder crashing] Janet, any chance this is a s \\
\hline 16 & there. - Gah! How can I help you? What the fork? Who are you? I'm Janet. I'm the \\
\hline 17 & top this train! [train screeching] Dude, what the fork? You're not leaving. Not with her. Not yet. \\
\hline 18 & dity and your indecisiveness. [playful music] Oh, fork! You're right. Every friend, every girlfriend was \\
\hline 19 & the stink eye. Eleanor, everyone hates you. Well, fork you too. No, this is good. Now that we \\
\hline 20 & 're snorting the concept of time? Yeah, it'll fork you up. Yo, monk dude, you know how to \\
\hline
\end{tabular}

(Prepared by authors, 2021)

The same procedure was applied for the other words. Fragments with the lemma "fork" and its inflected forms are shown in Figure 3.

Figure 3: Excerpts with wordplays produced with "fork" and its inflected forms

\begin{tabular}{|l|c|}
\hline excerpts & Episode \\
\hline Somebody royally forked up. & 1 \\
Ah, fork me. & 1 \\
... oh, fork. & 1 \\
What the fork? Who are you? & 1 \\
Yeah, but I forkin' nailed it. & 1 \\
Why can't I say "forked"? & 1 \\
Motherforker! & 1 \\
\hline
\end{tabular}




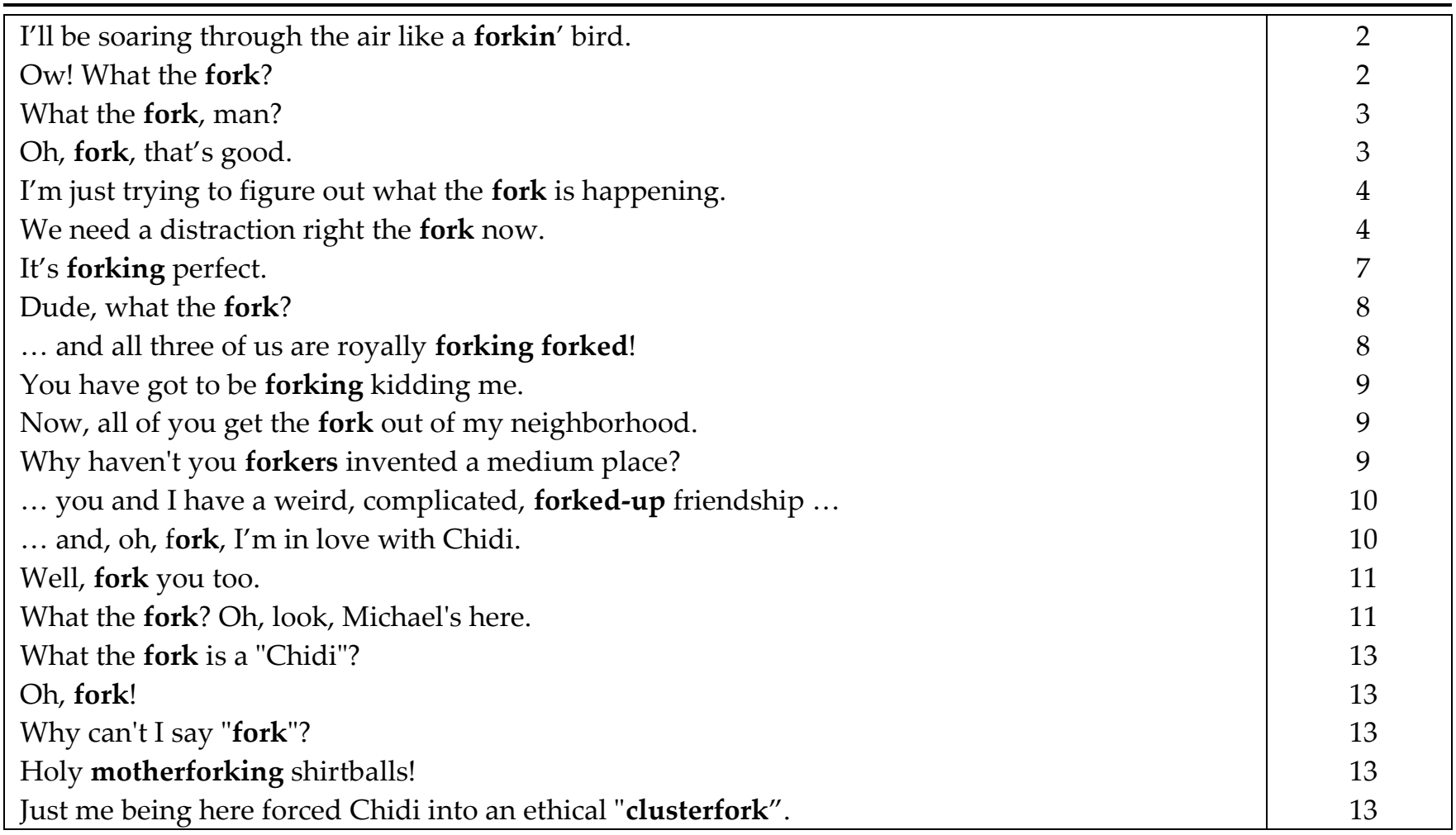

(Prepared by authors (2021)

All in all, the result was a collection of 28 wordplays, considered as such, because, as already mentioned, they all were produced through paronymy, "i. e. the use of words with only a slight difference in the surface form", "a formal similarity" that is "weaker than in homonymy but still strong enough for the two words to be related to each other in the mind of the listener or reader" (De Vries A, Verheij A J C, 1997: 76), or in the mind of the viewer, as in the case of AVT. This way, paronymy perfectly fits into the way we defined a wordplay, since it is an instantiation of a clever and creative manipulation through confronting two terms, in this case, "fuck" and "fork", causing in viewers a primary reaction of surprise, and then, producing a humorous effect.

Considering the excerpts in the source language, we can see the camouflaged swear words being used in varied ways, as their non-euphemistic correspondents would, some of them falling into the five categories established by Pinker (qtd. in Gedik 2020: 20), and discussed by Crysmasari (2018), as shown in Figure 5:

Figure 5: Swear words categories

\begin{tabular}{|l|l|l|}
\hline Categories & Taboo words are used: & Examples \\
\hline Descriptive swearing & literally & Let's fuck. \\
\hline Idiomatic swearing & metaphorically & It's fucked up. \\
\hline Abusive swearing & offensively & Fuck you! \\
\hline Emphatic swearing & as intensifiers & It's fucking amazing! \\
\hline Cathartic swearing & as a reflection of the speaker's feelings and emotions & Fuck! \\
\hline
\end{tabular}

(Prepared by authors, 2021) 
Such variation in the wordplays in English was possible thanks to the particularities of this language that allow a word to move from one lexical category to another without any change in its base form, as in "fuck"; on top of that, the possibility of replacing it with a single word ("fork") and its inflections eventually ensured complete consistency in the creation of the euphemistic swear words. Considering "fuck" and "fork" as nouns, for example, by means of a simple word formation process - suffixation - they can easily change from this word class into others; in Portuguese, however, "foda", the non-euphemistic correspondent noun for "fuck", would have to go through more complex word formation processes to change into all other categories, as we will see in our analysis.

In view of that, it would be difficult to find a sole paronymous item in Portuguese capable of generating so many suitable variations, like in English. Additionally, this difficulty is increased when we think of swear words as expressive formulae (Roos qtd. in Szerszunowicz 2012: 328), which, like other types of speech act formulae (or routine formulae), "are relatively inflexible phrasemes which are recognized by the members of a language community as preferred ways of performing certain functions such as greetings, compliments, invitations, etc." (Granger \& Paquot 2008: $44)$, to this group of expressive formulae or stock phrases, we add cursing.

Considering, then, that swear words are expressed by means of relatively fixed combinations, this leaves little room for significant interventions, and non-compositionality becomes a key factor. Non-compositionality "refers to cases when the meaning of the whole is not equal to the sum of the meanings of the individual elements" (Wikberg 2008: 128). Returning to Figure 5 above, descriptive swearing (Let's fuck!), for instance, seems not to fit into the "rule of noncompositionality". Its literal feature gives it flexibility, and if the verb is replaced, Let's screw/have sex/make love/get laid/have intercourse/copulate!, the meaning is preserved, but not the register, which moves on a continuum from colloquial to scientific terms. If, however, we take idiomatic swearing, It's fucked up!, such flexibility is drastically reduced, and we can basically come up with "It's screwed up!". This limited combinability reinforces its non-compositional character and reveals its metaphoric component.

Thus, before going into the analysis proper, we must discuss the possible pragmatic counterparts in Portuguese for non-euphemistic expressions using "fuck" in different forms, also considering the formulaic character of swear words. Pragmatic counterparts are expressions with equal or similar status; in this case, they must be considered offensive words as well. In Figure 6, we compare English and Portuguese swear words. It is worth mentioning that the selection of prima facie and pragmatic counterparts in Portuguese was based on our experience as native speaker of this language and later checked in a dictionary viii through their usage notes: offensive, vulgar, or the like. Some of the pragmatic expressions can be considered as analogs, that is, variant forms which exhibit similar or comparable elements to one or more components of another form in general or in some specific feature (Brezolin 2021).

\footnotetext{
viii Aulete Digital - o dicionário da língua portuguesa na internet. 2021. https://www.aulete.com.br/site.php?mdl=aulete digital (April 20, 2021)
} 
BAD WORDS IN THE GOOD PLACE: ANALYZING THE EUPHEMISTIC FUNCTION OF WORDPLAYS IN SUBTITLING AND DUBBING - A CASE OF ENGLISH AND PORTUGUESE LANGUAGE PAIR

\begin{tabular}{|c|c|c|}
\hline \multicolumn{3}{|c|}{ Figure 6: Comparing "fuck" expressions with their possible counterparts in Portuguese } \\
\hline English & & Portuguese \\
\hline & prima facie & other pragmatic possibilities \\
\hline It's fucked up. & Tá fodido(a). & $\begin{array}{l}\text { A coisa tá foda. } \\
\text { [The thing is fucked-up.] }{ }^{\text {ix }}\end{array}$ \\
\hline $\begin{array}{l}\text { Fuck you! } \\
\text { Fuck yourself! } \\
\text { Go fuck yourself! }\end{array}$ & $\begin{array}{l}\text { Foda-se! } \\
\text { Vai se foder! }\end{array}$ & $\begin{array}{l}\text { Vai tomar no (seu) cu! } \\
\text { (Up your ass!) }\end{array}$ \\
\hline Motherfucker! & & $\begin{array}{l}\text { Filho da puta! } \\
\text { (Son of a bitch!) }\end{array}$ \\
\hline What a fucking movie! & Que filme foda! & $\begin{array}{l}\text { Que puta filme! } \\
\text { [What a bitchy movie!] } \\
\text { Que filme do caralho! } \\
\text { [What a cocky movie!] }\end{array}$ \\
\hline Fuck! & É foda! & $\begin{array}{l}\text { Porra! [Cum!] } \\
\text { Caralho! [Cock!] } \\
\text { Cacete! [Dick!] } \\
\text { Merda! (Shit!) } \\
\text { Bosta! (Crap!) } \\
\text { Puta que (te) pariu! } \\
\text { [The whore that bore you!] }\end{array}$ \\
\hline
\end{tabular}

(Prepared by authors, 2021)

Now, we move to our analysis.

\section{Analysis and findings}

Figure 7 shows how the wordplays collected from the series were translated into Brazilian Portuguese, both in the dubbed and subtitled versions, and whether they resulted in wordplays or not.

Figure 7: Wordplays in original dialogue, dubbed version and subtitled version

\begin{tabular}{|r|l|l|l|l|l|}
\hline & Original & \multicolumn{1}{|c|}{ Dubbed version } & \multicolumn{1}{c|}{ Pun? } & \multicolumn{1}{c|}{ Subtitled version } & \multicolumn{1}{c|}{ Pun? } \\
\hline 1 & Somebody roally forked up. & $\begin{array}{l}\text { Alguém realmente fedeu } \\
\text { a coisa toda. }\end{array}$ & Yes. & Alguém flerrou com tudo. & Yes. \\
\hline 2 & Ah, fork me. & Ah, "tô fedida" & Yes. & Que baralho. & Yes. \\
\hline 3 & .. oh, fork. & Fedeu. & Yes. & Flerrou. & Yes. \\
\hline 4 & What the fork? Who are you? & $\begin{array}{l}\text { Que borra é essa? Quem é } \\
\text { você? }\end{array}$ & Yes. & $\begin{array}{l}\text { Mas que "zorra"? Quem é } \\
\text { você? }\end{array}$ & Yes. \\
\hline 5 & Yeah, but I forkin' nailed it. & $\begin{array}{l}\text { É borra, mas eu arrasei, } \\
\text { né?. }\end{array}$ & Yes. & Sim, mas eu consegui. & No. \\
\hline 6 & Why can't I say "fork"? & $\begin{array}{l}\text { Por que que não consigo } \\
\text { dizer "feder"? }\end{array}$ & Yes. & $\begin{array}{l}\text { Por que não conseguir dizer } \\
\text { "flerrou"? }\end{array}$ & Yes. \\
\hline 7 & Motherforker! & Filho da "fruta"! & Yes. & Filho da "juta"! & Yes. \\
\hline
\end{tabular}

ix From now on, expressions within square brackets are explanatory literal renditions. 
BAD WORDS IN THE GOOD PLACE: ANALYZING THE EUPHEMISTIC FUNCTION OF WORDPLAYS IN SUBTITLING AND DUBBING - A CASE OF ENGLISH AND PORTUGUESE LANGUAGE PAIR

\begin{tabular}{|c|c|c|c|c|c|}
\hline 8 & $\begin{array}{l}\text { I'll be soaring through the air } \\
\text { like a forkin' bird. }\end{array}$ & $\begin{array}{l}\text { Eu vou estar voando bem } \\
\text { alto como um pássaro. }\end{array}$ & No. & $\begin{array}{l}\text { Eu estaria planando no ar } \\
\text { como um pássaro. }\end{array}$ & No. \\
\hline 9 & Ow! What the fork? & Que “borra" é essa? & Yes. & O que é isto? & No. \\
\hline 10 & What the fork, man? & Mas, que borra, cara! & Yes. & Mas, que zorra, cara! & Yes. \\
\hline 11 & Oh, fork, that's good. & Borra, que bom! & Yes. & Nossa, isso é bom. & No. \\
\hline 12 & $\begin{array}{l}\text { I'm just trying to figure out } \\
\text { what the fork is happening. }\end{array}$ & $\begin{array}{l}\text { Só tentando descobrir que } \\
\text { borra é essa. }\end{array}$ & Yes. & $\begin{array}{l}\text { Só estou tentando entender } \\
\text { que diabos está } \\
\text { acontecendo. }\end{array}$ & No. \\
\hline 13 & $\begin{array}{l}\text { We need a distraction right } \\
\text { the fork now. }\end{array}$ & $\begin{array}{l}\text { Temos q distrair o povo e } \\
\text { esta borra tem que ser } \\
\text { feita agora. }\end{array}$ & Yes. & $\begin{array}{l}\text { Precisamos de uma porcaria } \\
\text { de distração agora. }\end{array}$ & No. \\
\hline 14 & It's forking perfect. & É perfeito pra baralho. & Yes. & É perfeito. & No. \\
\hline 15 & Dude, what the fork? & O meu, que borra é essa? & Yes. & Cara, o que foi? & No. \\
\hline 16 & $\begin{array}{l}\text {... and all three of us are } \\
\text { royally forking forked! }\end{array}$ & $\begin{array}{l}\text { E nós três estamos } \\
\text { fedidos pra baralho. }\end{array}$ & Yes. & $\begin{array}{l}\text { E nós três estamos } \\
\text { completamente ferrados. }\end{array}$ & No. \\
\hline 17 & $\begin{array}{l}\text { You have got to be forking } \\
\text { kidding me. }\end{array}$ & $\begin{array}{l}\text { Vc só pode estar zoando } \\
\text { com a minha cara. }\end{array}$ & No. & $\begin{array}{l}\text { Vc deve estar zoando com a } \\
\text { minha cara. }\end{array}$ & No. \\
\hline 18 & $\begin{array}{l}\text { Now, all of you Get the fork } \\
\text { out of my neighborhood. }\end{array}$ & $\begin{array}{l}\text { Saiam da borra do meu } \\
\text { bairro. }\end{array}$ & Yes. & $\begin{array}{l}\text { Saiam de vez da minha } \\
\text { vizinhança. }\end{array}$ & No. \\
\hline 19 & $\begin{array}{l}\text { Why haven't you forkers } \\
\text { invented a medium place? }\end{array}$ & $\begin{array}{l}\text { Poe que } \mathrm{n} \text { inventaram } \\
\text { uma borra de um lugar } \mathrm{q} \\
\text { fosse no meio? }\end{array}$ & Yes. & $\begin{array}{l}\text { Por que vcs não inventaram } \\
\text { um lugar médio? }\end{array}$ & No. \\
\hline 20 & $\begin{array}{l}\text {... you and I have a weird, } \\
\text { complicated, forked-up } \\
\text { friendship ... }\end{array}$ & $\begin{array}{l}\text {... eu e vc temos uma } \\
\text { amizade estranha, } \\
\text { complicada e fedida ... }\end{array}$ & Yes. & $\begin{array}{l}\text {... eu e você temos uma } \\
\text { amizade, estranha, } \\
\text { complicada ... }\end{array}$ & No. \\
\hline 21 & $\begin{array}{l}\ldots \text { and, oh, fork, I'm in love } \\
\text { with Chidi. }\end{array}$ & $\begin{array}{l}\text { Borra, baralho, eu tô } \\
\text { apaixonada por ele. }\end{array}$ & Yes. & $\begin{array}{l}\text {... nossa, eu estou } \\
\text { apaixonada pelo Chidi. }\end{array}$ & No. \\
\hline 22 & Well, fork you too. & Vai se feder vc tb. & Yes. & Dane-se vc. tb. & No. \\
\hline 23 & $\begin{array}{l}\text { What the fork? Oh, look, } \\
\text { Michael's here. }\end{array}$ & Mas q lerda! & Yes. & Que borra! & Yes. \\
\hline 24 & What the fork is a "Chidi"? & Que borra é um Chidi? & Yes. & Que "orra" é um Chidi? & Yes. \\
\hline 25 & Oh, fork! & Oh, "borra"! & Yes. & Oh, droga! & No. \\
\hline 26 & Why can't I say "fork"? & $\begin{array}{l}\text { Por que q eu posso não } \\
\text { dizer "borra"? }\end{array}$ & Yes. & $\begin{array}{l}\text { Por que não consigo dizer } \\
\text { "orra"? }\end{array}$ & Yes. \\
\hline 27 & $\begin{array}{l}\text { Holy motherforking } \\
\text { shirtballs! }\end{array}$ & $\begin{array}{l}\text { Fruta q pariu não acredito } \\
\text { nessa borra toda. }\end{array}$ & Yes. & Minha santinha do pau oco. & No. \\
\hline \multirow[t]{2}{*}{28} & $\begin{array}{l}\text { Just me being here forced } \\
\text { Chidi into an ethical } \\
\text { "clusterfork". }\end{array}$ & $\begin{array}{l}\text { A minha presença aqui } \\
\text { causou uma confusão } \\
\text { ética no Chidi. }\end{array}$ & No. & $\begin{array}{l}\text { Por eu estar aqui, isso levou } \\
\text { Chidi a uma confusão ética }\end{array}$ & No. \\
\hline & & Totals & $\begin{array}{l}\text { Yes. } \\
(25) \\
\text { No. (3) }\end{array}$ & & $\begin{array}{l}\text { Yes. } \\
\text { (10) } \\
\text { No. } \\
(18)\end{array}$ \\
\hline
\end{tabular}

(Prepared by authors, 2021)

Based on the data above, in quantitative terms, we can notice that $89 \%$ of the wordplays in the dubbed version were successfully transferred into the target language, against only $35 \%$ of the solutions in the subtitled version. This way, 25 occurrences in the dubbed version against 10 in 
the subtitled version were "adapted to the local setting, to maintain humorous effect", and 3 occurrences in the dubbed version against 18 in the subtitled version were "replaced by nonwordplay" (Gotlieb 1997), or replaced by non-wordplay with omission, preserving or not the humorous effect.

As to the mechanisms adopted to recreate the wordplays in the target language, paronymy, as expected, was by far the most used. As mentioned before, if only one paronymous item ("fork"/ "fuck") was enough to create a series of wordplays with the base form acquiring different word classes in English, in the target language, different interventions were necessary, as it can be observed in Figure 8, where we compare "fork" and its inflections with the words and expressions employed to reproduce the wordplays in Portuguese.

Figure 8: Solutions with paronymous words in Portuguese

\begin{tabular}{|l|l|l|}
\hline English & \multicolumn{2}{|c|}{ dubbing } \\
\hline & \multicolumn{1}{|c|}{ Portuguese } \\
\hline forked up & fedeu & flerrou \\
\hline fork me & fedida & baralho \\
\hline oh, fork & fedeu & flerrou \\
\hline what the fork & borra (5) & zorra \\
\hline forking & borra; baralho & $\varnothing$ \\
\hline fork & feder (2); borra (3); borra, baralho; lerda & flerrou; borra; orra \\
\hline motherfucker & filho da fruta & filho da juta \\
\hline forking forkerd & fedidos pra baralho & $\varnothing$ \\
\hline forkers & borra & $\varnothing$ \\
\hline forked-up & fedida & $\varnothing$ \\
\hline motherfucking & fruta que pariu & $\varnothing$ \\
\hline
\end{tabular}

(Prepared by authors, 2021)

From now on, we explore the wordplays found in the series. In the dubbed version (excerpts 4 , $5,9,10,11,12,13,15,18,19,21,24,25,26$, and 27), "borra", literally "dregs", was the most used in the place of "porra" ["cum"], it is the perfect paronymous choice since only one phoneme makes them apart, and both are bilabial minimal pairs, resulting in an effective "soundplay". It was also used in the subtitled version (excerpt 23) along with other paronymous items (excerpts 4, 10, and 26), "zorra" ("mess") and "orra" (shortened form of "porra"), which also fulfilled the objective of circumventing swear words, but, perhaps, not so effectively as "borra", due to its higher phonological proximity.

Doubtlessly, and for obvious reasons, the verb "feder" was very used in the dubbed version of the series. Compared with its non-euphemistic counterpart, "foder", one single vowel makes the difference, and "feder", an existing verb, which may mean "to stink" and "to complicate", also alludes to the metaphoric use of "fuck", "to be in trouble". Apart from that, "feder" allows similar inflections just as "foder": past tense, "fodeu/fedeu"; past participle/adjective, "fodida/fedida, "fodidos/fedidos" (reminding that adjectives in Portuguese vary according to number and gender). As it can be noticed, a perfect paronymous fit. Curiously, it was not used in the subtitles, where an inflection, "flerrou", of an invented verb, "flerrar", was used. To all 
appearances, it was created from the verb "ferrar-se", a slang for "to fail/to be unsuccessful", which is not a swear word, but already a euphemism for "foder-se". Consequently, it makes no sense in the series since the objective of the wordplays is to clearly camouflage bad words.

Other occurrences in both versions were successfully reproduced by means of effective paronymous terms and expressions:

a) "baralho" ("a pack of playing cards") in place of "caralho" ["cock"];

b) "lerda" (slow moving) in place of "merda" ("shit");

c) "filho da fruta" ["son of the fruit"]/“filho da juta" ["son of the jute"] in place of "filho da puta" ("son of a bitch"), and

d) "fruta que pariu" ["fruit that bore you"] in place of "puta que pariu" ("godamnit").

We also encountered two cases, both in the dubbed version, in which: 1. the use of a euphemistic term preceded by a euphemistic intensifier, "forkin forked", was equally transposed as "fedidos pra baralho" (excerpt 16), and 2. where the translation, in lieu of one euphemistic word in English, "oh, fork", used two terms, "borra, baralho", resulting in a stronger exclamation (excerpt 21).

In general terms, "baralho/caralho"; "lerda/merda"; "fruta, juta/puta" were also suitable choices, resulting in effective wordplays in the target language.

Now we turn to the solutions found, mainly in the subtitled version, in which the original wordplays were replaced by non-wordplays: "Só estou tentando entender que diabos está acontecendo." [I'm just trying to understand what the hell is going on here.", excerpt 12]; "Precisamos de uma porcaria de distração agora." [We need some rubbish distraction right now.", excerpt 13]; "E nós três estamos completamente ferrados." ["All three of us are completely busted.", excerpt 16]; "Dane-se vc. tb." [“Damn you too.", excerpt 22], and “Oh, droga!" [“Oh, damn!", excerpt 25]. In all these cases, it is possible to spot items referring to the source euphemistic wordplay, but they are being used in their "natural" form: "que diabos [what the hell]"; "porcaria [rubbish]"; "ferrados [busted]"; "dane-se [damn you]", and "droga [drug]", so they were regarded as ineffective solutions, since modified swear words are a must in the series.

Now, we present the cases, in the dubbed or subtitled version, or in both, in which the wordplays were replaced by non-wordplays with omission, preserving or not the humorous effect, where the wordplay is omitted and the whole fragment in which it appears is:

a) translated (almost) literally, as in excerpts 8, 17, and 28, in both the dubbed and subtitled versions: "Eu vou estar voando bem alto com um pássaro." "Eu estaria planando no ar como um pássaro." ["I will/would be soaring high in the air/through the air like a bird."]; "Vc só pode estar zoando com a minha cara." " Vc deve estar zoando com a minha cara." [You must be kidding me.], and "A minha presença aqui causou uma confusão ética no Chidi."/ Por eu estar aqui, isso levou Chidi a uma confusão ética." ["My presence/Just me being here caused Chidi an ethical confusion."]; respectively, and as in excerpts 9, 14, 15, 18, 19, 20, 21 and 27 of the subtitled version: "Sim, mas eu consegui." [Yes, but I was successful.]; "O que é isto?" [What is it?]; "É perfeito."[It's perfect.]; "Cara o que foi?" [Boy, what happened?]; "Saiam de vez da minha vizinhança." [Get out of my neighborhood right now.]; "Por que vcs não inventaram um lugar médio?" [Why haven't you invented a medium place?]; "... eu e você temos uma amizade, 
estranha, complicada ..."[... I and you have a weird, complicated friendship.]; ... nossa, eu estou apaixonada pelo Chidi." [... wow, I'm in love with Chidi.]; respectively. In all of them, the humorous effect was not preserved, and

b) replaced by something quite different from the source linguistic construction, as in excerpt 27, "Minha santinha do pau oco." [You are such a goody-goody.], in this case, we believe that the humorous effect was somewhat maintained.

As to our main objectives, considering the solutions in both versions (56), sixty-two-pointfive percent $(62.5 \%)$ of them were adapted to the local setting and the linguistic mechanisms to reproduce them preserved their pragmatic effect, that is, they were also constructed as wordplays, whose effect was also humorous. Though we considered the solutions in excerpts 1 , 3 and 6 of the subtitled version as wordplays, they fell short of expectations since, as already mentioned, the wordplays in the original were meant to conceal curse words, and not simply to disguise items already used euphemistically. As far as translation choices are concerned, the dubbed version is, by all odds, the most consistent by translating most of the wordplays (25/28), and by using the same euphemistic lexical items throughout the episodes. We also highlight the fact that the successful solutions in the target language do not configure verbatim renditions, but solutions that are equally formulaic (constructed from existing unchanged expressive stock phrases in Portuguese), and as such, suitable pragmatic euphemistic counterparts.

\section{Concluding remarks}

Our study has reinforced the idea that translating wordplays is a challenging task, and that, when AVT is involved, it becomes even more challenging due to the typical technical constraints (time and space) of this type of language transfer. Besides, from the linguistic point of view, translators must first notice a wordplay, understand how it was generated, and then, as far as possible, translate it as such, considering the particularities and potentialities of the target language. In the case of our study, the wordplays were so evident that this does not seem to be a reason for the inappropriate translation or omission of about $64 \%$ of them, mainly in the subtitled version.

In terms of possible solutions, it important that translators recognize the type of structure being used to create wordplays. In the case of phraseological units, expressive stock phrases, as in this article, translators must understand that the overall meaning of the combination cannot be predicted from the sum of the meanings of its isolated components, so he/she must resort to similar formulaic expressions in the target language and make the necessary interventions to reproduce similar wordplays with the same pragmatic effect. In our study, for example, the transformed combinations should resemble swear words from the formulaic point of view and result in humorous constructions, as it happened in $62,5 \%$ of the wordplays translated into Portuguese in the dubbed and subtitled versions. Yet, recognizing and reproducing the wordplays or finding other resources to offset their role is mandatory since their presence represents an important characterization of the protagonist's profile in the series analyzed.

Our results demonstrate that dubbing seems to be less restrictive on the use of swear words than subtitling, corroborating the idea, as we have mentioned, that multichannel 
television providers believe that listening to taboo words is less offensive than reading them. The results also demonstrate that translators seem to censure themselves, perhaps feeling uncomfortable to render taboo words as such, and eventually attenuating or omitting them. In either case, even when taboo words are camouflaged, there is resistance on the part of translators, maybe it is because the supposedly "disguised" swear words are still easily perceived by viewers. Though, in general terms, our perception is that subscription television channels, in Brazil, seem to have become less restrictive on the use of taboo terminology; anyhow, both issues leave room for further investigation.

In conclusion, as translating wordplays stimulates and calls for linguistic and metalinguistic reflection, we believe that exposing translation students to this kind of material, which offers insights from the linguistic, cultural, and pragmatic perspectives, can be a useful teaching tool.

\section{Conflict of Interest Statement}

The authors declare no conflicts of interests.

\section{About the Authors}

Adauri Brezolin holds a doctoral degree in English Language from the University of São Paulo, Brazil. He taught in several translation undergraduate programs for more than 30 years. He is the co-author of the following dictionaries: Pequeno Dicionário de Expressões Idiomáticas $e$ Coloquialismos (Fiuza, 2001), Whatchamacallit? Novo dicionário português-inglês de idiomatismos e coloquialismos (Disal, 2006), Happy Couples - dicionário de colocações lexicais adjetivas (Disal, 2010) e The word is the thing: dicionário português-inglês de fórmulas situacionais, frases feitas e provérbios (Lexikos, 2019). He has also published articles on the translation of wordplays, and other subjects (https://orcid.org/0000-0002-4990-0224). His research interests are the teaching of translation, idiomaticity, conventionality, terminology, and Corpus Linguistics. He is also a freelance translator.

Fernanda da Silva Medeiros earned a B. A. in Translation from the Methodist University of São Paulo, Brazil, in 2019. She is a private teacher of English and works as a freelance translator.

\section{References}

Anthony L, 2019. AntConc (Windows, Macintosh OS X, and Linux) Build 3.5.8, February 18, 2019. https://www.laurenceanthony.net/software.html/. Accessed: 4 February 2020

Arnaud P J L, Maniez F, Renner V, 2015 Non-Canonical Proverbial Occurrences and Wordplay: A Corpus Investigation and an Enquiry into Readers' Perception of Humour and Cleverness, Berlin/Boston: De Gruyter, pp. 135-159

Attardo S, 1994. Linguistic Theories of Humour. Berlin: Mouton de Gruyter 
Ávila-Cabrera J J, 2016. The treatment of offensive and taboo terms in the subtitling of Reservoir Dogs into Spanish. Trans 20: 25-40

Ballard M, 1996. Wordplay and the Didactics of Translation. The Translator 2:2: 333-346

Beseghi M, 2016. WTF! Taboo Language in TV Series: An Analysis of Professional and Amateur Translation. Altre Modernità, febbraio, 215-31. https://doi.org/10.13130/2035-7680/6859

Brezolin A, 2021. As lost as a pun in a corpus: an investigation into noncanonical phraseological occurrences in large corpora and translation. Tradterm 37(2): 460-487

Brezolin A, 2020a. Corpus Lift? The use of wordplays in translator training classes. Skopos. Revista Internacional de Traducción e Interpretación 11: 211-236

Brezolin A, 2020b. O humor está no ar: análise comparativa da tradução de jogos de palavras fraseológicos em texto literário. Revista de Estudos da Linguagem 28: 359-389

Crysmasari R P, 2018. Swear words uttered by the main characters in TED 2 movie. Master Thesis, Sanata Dharma University, Indonesia

Darta D M S, 2020. Misconstructing Characters: A Critical Look at the Translation of the Swearing Words. Teknosastik 18(1): 25-32

De Vries A, Verheij A J C, 1997 A Portion of Slippery Stones. Wordplay in Four TwentiethCentury Translations of the Hebrew Bible, Manchester: St. Jerome Publishing, pp. 67-94

Delabastita D, 1996 Introduction, Wordplay and Translation: Special Issue of 'The Translator', Manchester, UK, pp. 127-139

Diaz Cintas J, Orero P, 2010. Voiceover and Dubbing, Amsterdam/Philadelphia: John Benjamins Publishing Company, pp. 441-445

Diaz Cintas, J, 2010. Subtitling, Amsterdam/Philadelphia: John Benjamins Publishing Company, pp. 344-349

Dore M, 2010 The audiovisual translation of fixed expressions and idiom-based puns, València, Spain, pp. 361-386

Gedik T A, 2020. Translation of Turkish Swear Words in Subtitling: GORA. International Journal of English Language and Translation Studies 8: 19-26

Giordadze M, 2014. Linguistic features of pun, its typology and classification. European Scientific Journal (Special Edition) 2: 271-275

Gottlieb H, 1997. You Got the Picture? On the Polysemiotics of Subtitling Wordplay, Manchester:

St. Jerome Publishing, pp. 207-232

Granger S, Paquot M F, 2008. Disentangling the phraseological web. Amsterdam/Philadelphia: John Benjamins, pp. 27-49

Langlotz A, 2006. Idiomatic Creativity: A Cognitive-Linguistic Model of Idiom Representation and Idiom Variation in English. Amsterdam: Benjamins

MacArthur T, 1992. The Oxford Companion to the English Language. Oxford: Oxford University Press

Medeiros F da S, 2019. Análise comparativa da tradução de jogos de palavras eufemísticos na legendagem e dublagem da série The Good Place. Undergraduate Dissertation, Methodist University of São Paulo, Brazil 
Moon R, 1998. Fixed Expressions and Idioms in English. Corpus Lexicography. Oxford: Clarendon Press

Nunes E A T, 2012. A legendagem da televisão por assinatura do Brasil. Master Thesis, University of São Paulo

Redfern, W. 1984. Puns, New York, NY, USA

Remael A, 2010. Audiovisual Translation. Amsterdam/Philadelphia: John Benjamins Publishing Company, pp. 12-17

Renner V, 2015 Lexical Blending as Wordplay, Berlin/Boston: De Gruyter, pp. 119-133

Robati F Z N, Zand F, 2018. Translation of taboos: the absolutely true diary of a part-time Indian. International Journal of Applied Linguistics \& English Literature 7(3): 35-40

Silva N R B, 2019 A tradução de jogos de palavras em um corpus literário: uma revisão do modelo de Delabastita com o auxílio da linguística de corpus. Ilha do Desterro 72(2): 347378

Szerszunowicz J, Routine Formulae and Culture: On Polish Hospitality Scenario and Phraseology. Tendências atuais na pesquisa descritiva e aplicada em fraseologia e paremiologia II: 327-342

Tagnin S E O, 2005 O humor como quebra da convencionalidade. Revista Brasileira de Linguística Aplicada 5(1): 247-257

Veisbergs A, 1997 The contextual use of idioms, wordplay, and translation, Manchester: St. Jerome Publishing, pp. 155-176.

Viégas-Faria B, 2004. Soluções tradutórias para a alteração contextual de provérbios em Júlio César, de Shakespeare. Letras de Hoje 39(1): 195-214

Wikberg K, 2008. Phrasal similes in the BNC. Amsterdam/Philadelphia: John Benjamins, pp. 127142

Zirker A, Winter-Froemel E, 2015 Wordplay and Its Interfaces in Speaker-Hearer Interaction: An Introduction, Berlin/Boston: De Gruyter, pp. 1-22 

to their work. Under the terms of this license, no permission is required from the author(s) or publisher for members of the community to copy, distribute, transmit or adapt the article content, providing a proper, prominent and unambiguous attribution to the authors in a manner that makes clear that the materials are being reused under permission of a Creative Commons License. Views, opinions and conclusions expressed in this research article are views, opinions and conclusions of the author(s). and European Journal of Literature, Language and Linguistics Studies shall not be responsible or answerable for any loss, damage or liability caused in relation to/arising out of conflicts of interest, copyright violations and inappropriate or inaccurate use of any kind content related or integrated into the research work. All the published works are meeting the Open Access Publishing requirements and can be freely accessed, shared, modified, distributed and used in educational, commercial and non-commercial purposes under a Creative Commons Attribution 4.0 International License (CC BY 4.0). 